\title{
Recognition and Strengthening the Customary Land Ownership in Central Borneo Province
}

\author{
Nur Putri Hidayah"1, Sholahuddin Al-Fatih², \\ 1 Fakultas Hukum, Universitas Muhammadiyah Malang, nurputri@umm.ac.id \\ 2 Fakultas Hukum, Universitas Muhammadiyah Malang, salfatih@umm.ac.id
}

\begin{abstract}
Introduction to The Problem: The rapid flow of globalization has brought indigenous peoples to prolonged horizontal and vertical conflicts. The majority of conflicts triggered by who has the right to own the land and functionalize it. The land that belongs to indigenous peoples and it inherited from generation to generation, suddenly taken by investors and it even supported by the government. The indigenous people are often victimized and forced out from their customary lands. They who try to claim the rights sometimes experience obstacles because of the stronger and dominant government position in the court. One of these conflicts occurred in the Dayak community in Central Borneo Province.
\end{abstract}

Purpose/Objective Study: This study aims to determine the problems experienced by indigenous peoples in Central Borneo Province, as well as to find out the mechanism for establishing a legal protection system in order to provide recognition and strengthening ownership of customary land in the Central Borneo Province.

Design/Methodology/Approach: This study uses normative research methods, with statute approaches and conceptual approaches.

Findings: there are serious problems experienced by indigenous people in Central Borneo Province, related to customary land in their territory. However, there are legal safeguards that can be carried out through formal and administrative land recognition.

Paper Type: Research Article

Keywords: Recognition; Ownership; Customary Land; Central Borneo

\section{Introduction}

The position of land for the Indonesian people is at a primary level due to the agrarian style that is owned by the people in Indonesia (Alting, 2011). Also, the relationship between the community and the land aligns with the relationship between the community and God, where both have become philosophical foundations in Indonesia (Yusuf, 2016). For indigenous people, the land is their mother, where it is a place of residence for them and their ancestor's spirits, cultural/sacred sites as well as a place to earn a living and guarantees traditional survival (Yusuf, 2016).

Normatively, the relationship between customary law communities and the land is recognized by the state in various laws and regulations. First, the land is an integral 
component of the lives of indigenous peoples. This very close relationship clearly stated in the explanation of Article 67 Paragraph (1) of Act No. 41 of 1999 concerning Forestry that forests are a place for indigenous and tribal peoples to fulfill their daily needs (Indonesian Forestry Act, 1999). Second, the customary land is the first authority owned by indigenous peoples based on Act No. 5 of 1960 concerning Basic Regulations on Agrarian Principles (from now on abbreviated as UUPA (Indonesian Basic Regulations on Agrarian Principles, 1960).

Customary rights provide specific authority to indigenous peoples to their customary land, which is the source, basis of implementation, and the provisions for the procedure for implementation are the relevant customary law. The authority covers land tenure rights by its citizens and the release of land for the needs of "outsiders." Considering that customary law is dynamic, then land tenure rights obtained according to customary law by the people of the indigenous community concerned if desired may be registered as land rights according to the UUPA. Third, those indigenous peoples as part of Indonesian citizens (WNI) can be recognized if they have bright customary law areas, as explained in Act No. 41 of 1999 on Forestry, Article 67 Paragraph (1) (Indonesian Forestry Act, 1999). Therefore, mapping is essential as authentic evidence of the existence of indigenous peoples with indigenous territories as their area of life and ownership and upholding applicable customary law.

From the above explanation, it concludes that an authentic proof of tenure and the boundary of customary land are significant for indigenous peoples. Whatever the programs concerned with forestry, mining, and plantations, they all are unable to effectively run if there is uncertainty about land ownership by indigenous peoples (Cotula \& Mayers, 2010). Underestimate the needs of indigenous peoples for land means sacrificing social justice (Yono \& Permadi, 2016) and the environment of indigenous peoples as landowners and users who have, with their local wisdom, proved to be able to preserve the natural resources (Hidayat, 2011). The need for land for the indigenous community was recognized in the 1992 Earth Summit in Rio de Janeiro with the issuance of the Rio Declaration on Environment and Development. In Principle No. 22, it states that indigenous peoples have a vital role in the management and development of the environment because of their traditional knowledge and practices (The Rio Declaration on Environment and Development, 1992).

In the present context, there are several regions in Indonesia, which de facto and de jure recognize the ownership of land by indigenous peoples. One of them is the Province of Central Borneo, a region that recognizes the existence of indigenous peoples and their traditional institutions. It looked from the existence of customary institutions and the recognition of the Central Borneo Dayak as indigenous people and their rights which stipulated in Provincial Regulation No. 16 of 2008 concerning 
Dayak Indigenous Institutions in Central Borneo (Provincial Regulation on Dayak Customary Institution, 2008).

The indigenous people of Central Borneo are called Dayaks. Dayak is "a Central Borneo tribe who have customary rights, cultures, and customary law which recognized as manifestations of Bhinneka Tunggal Ika (The Unity in Diversity), in the frame of the Unitary of Indonesian Republic." In carrying out customs, of course, requires institutions and traditional institutions. Dayak adat institutions and customary institutions in Central Borneo depicted, as shown in the diagram below (Hidayah, 2013):

Picture 1. Central Borneo Dayak adat Institutional structure

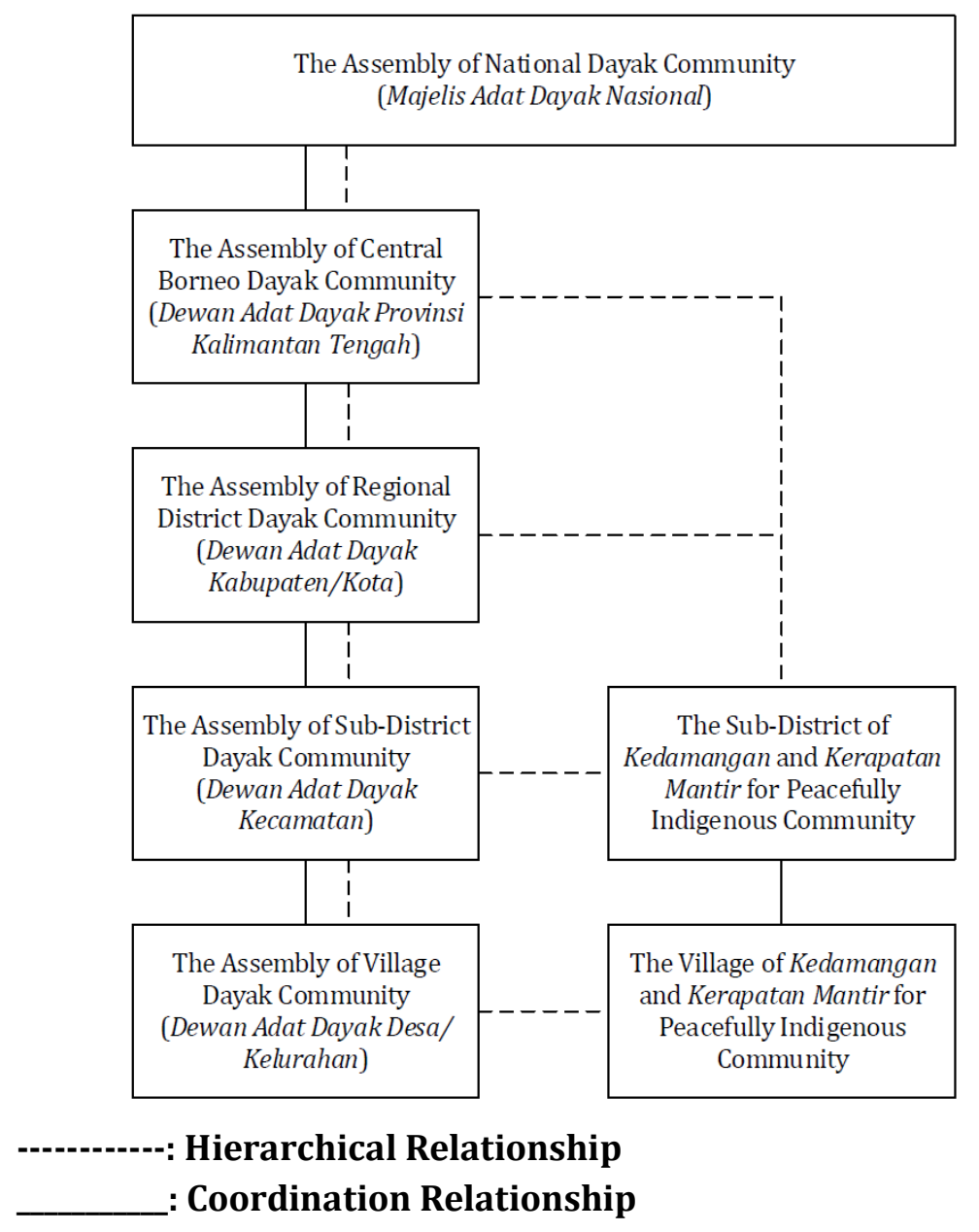

After the existence of adat institutions is recognized, the problem that arises then is related to the recognition of the customary land rights of the indigenous peoples themselves. Based on this background, this article discusses the efforts of the state, especially the Central Borneo Regional Government to recognize and strengthen the 
Jurnal Hukum

status of customary land of customary law communities in the Central Borneo Province.

\section{Methodology}

The research method in writing this article uses normative research methods (Soekanto, 2006). The purpose of this study was to find out how the state's efforts, especially the Central Borneo regional government, to recognize and strengthen the status of customary land of customary law communities in the Central Borneo Province.

The type of analytical research in this article is descriptive-analytic (Soekanto, 2006). To be able to answer the problem statement, this study used a statute approach and conceptual approach (Marzuki, 2010). Based on the source, the type of data used is secondary data, which includes legislation, books, scientific articles and journals, dictionaries, and others. In detail, the secondary data used consists of primary legal materials, secondary legal materials, and tertiary legal materials.

\section{Analysis and Results}

\section{Problems in State Recognition of the Existence of Indigenous and Indigenous Peoples}

Indonesia, through the concept of a nation-state, has to recognize the existence of society, groups, and indigenous peoples as the nation and state forming components. Therefore, mapping customary territories as proof of the existence of indigenous peoples and their territories is a form of legal protection (Sugiswati, 2012) which can be given by the government to recognize the existence of customary territory, customary law, and customary rights attached to them as a community. The principle of legal protection for customary law communities as part of the Indonesian people towards government actions rests and based on the concept of recognition and protection of human rights (Hadjon, 2013).

The principle of legal protection for the people of Indonesia is the principle of recognition and protection of human dignity and values which derived from the Pancasila and the principle of the rule of law based on Pancasila. Pancasila itself is the basis of the state in the sense of a country's state ideology and its life philosophy. As an ideology or as a philosophy of life by itself, the Pancasila becomes a guideline for the behavior of the state and its people in it.

The indigenous communities have long existed before the Republic of Indonesia formally formed. The order of life and culture, geographical location, and customary law make the characteristics of human resources in Indonesia are varied (Salim, 2016). Their existence is then recognized by the constitution through Article $18 \mathrm{~B}$ Paragraph (2) of 1945's Indonesia's Constitution. It states that "The State recognizes and respects customary law community units along with their traditional rights as long as they are alive and in accordance with the development of the people and 
principles of the Unitary State of the Republic of Indonesia regulated in law (The 1945 Constitution of the Republic of Indonesia, 1945)." The article is a legal base that recognized the right of indigenous people for their land. Thus, it is illegal for another party to take over the land without the authorization of the local community, even if this party is from the government (Pasamai, Husen, Rahman, \& Maisa, 2017).

The customary land rights sourced from the explanation of UUPA Article 3 No. 5 of 1960 which states, "customary rights and similar rights in the customary law library called as 'Beschikkingsrecht,' which means "ownership rights." The customary rights itself recognized with two conditions that are the reality is still there and acknowledged (Indonesian Basic Regulations on Agrarian Principles, 1960).

Furthermore, the existence of indigenous peoples and their lands (customary forests) recognized in Article 1 number (6) of Act No. 41 of 1999 concerning Forestry. It explains that "Customary forests are state forests within the territory of the indigenous people (Indonesian Forestry Act, 1999)." However, such recognition is not clear enough because of the definition of Customary Forests which still covered in State Forests and did not freely separate. That is why the definition of Customary Forest revised through the decision of the Constitutional Court No. 35/PPU-X/2012, which states that "Customary Forests are forests within the territory of indigenous peoples (Indonesian Constitutional Court, 2012)." It means that Customary Forest is no longer part of State Forest like it was in Article 5 Paragraph (1) of Law No. 41/1999 concerning Forestry. The revision has a juridical outcome that management of customary forests is entirely the right of the indigenous people as its owner (Pasamai et al., 2017).

\section{Rights of Indigenous Peoples to Customary Land}

The existence of indigenous peoples and their land ownership begins with land clearing (Wardani, 2018), both for living or working. Every Indonesian citizen has the right to open forest land that has not been opened or controlled by people, to be his residence or transform it to become a field, and as a place to preserve his family's life (Soekanto, 2011). The land that opened for the first time in a single transaction carried out by people who open it and become their property.

The right to clear the land stipulated in UUPA Article 16 paragraph 1 (f), and it detailed further in Article 46 paragraph (1) that Indonesian citizens can only own the right to open the land and collect forest products through the government regulations (Indonesian Basic Regulations on Agrarian Principles, 1960). Further, Hadikusuma said that the land clearing based on two approvements and it depends on who clears the land. First, the land cleared by the community within their customary land right area is carried out by the permission of the elders. Second, they who come and open the land from another community's customary land right area is carried out by the community's approvement. It was like experienced by 


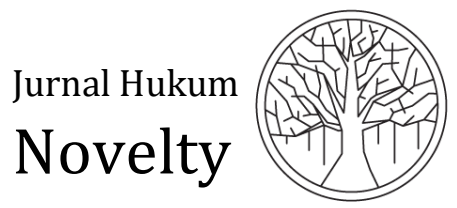

Volume 10, Issue 01, 2019, pp. 11-22

P-ISSN: $1412-6834$

E-ISSN: 2550-0090

Rebang Kasuy People from North Lampung that approved by the Elders of Marga Buway Bahuga Clan The land ownership can also be carried out by an individual by clearing a forest, so then it will gradually become an individual property in the sense of "Indonesian property" (Inlande bezitsrecht) (Hadikusuma, 1999).

Pure customary land law has a communalistic concept which embodies cooperation and family spirit (Puri \& Sulastriyono, 2016) and is filled with a religious atmosphere as is the nature of indigenous peoples themselves. This customary land law is then called customary Rights. Boedi Harsono, an agrarian law expert, stated that customary rights are a series of authority and obligations of an indigenous community, which relates to land located within its territory and is a significant supporter of the livelihoods and lives of indigenous peoples (Harsono, 2013).

The customary rights itself cover all land within the territory of the indigenous peoples concerned, both those who have been in someone's rights and those who have not. Generally, the coverage area is unmeasured in a certain way. For example in the Dayak tribe, there are various ways to determine the size of their territories such as using the sound of gongs and how far it is heard or by the boundaries of particular trees that have been planted by them (Puri \& Sulastriyono, 2016).

The customary rights have the legal force that applies internally and externally (Rosalina, 2010). The internal legal force means it relates to its citizens who own the rights. This internal aspect tied internally within the indigenous community so that the community preserves the land as their obligation. Meanwhile, the external legal force relates to the people who are living apart from indigenous peoples not to enter illegally, and they will penally-punished in doing so (Harsono, 2013). If they legally are entering the customary are, they obliged to provide goods to indigenous authorities called Pengisi Adat (Malaka, 2018).

In addition to the customary rights in the lives of indigenous peoples, it also exists the Indigenous Land Ownership Rights. The Individual rights which subsequently exist on customary land are actually from these joint rights (the common area). However, the customary often misinterpreted as collective ownership even though it is not like that. Normatively, individual ownership of the customary rights contained in the general explanation of Chapter II of UUPA, which states that "in the context of customary rights there is the existence of private property right (Indonesian Basic Regulations on Agrarian Principles, 1960)." The relationship between customary land and private land is unstable. The customary rights will strengthen if individual rights are gradually gone (not managed by the owner) and vice versa.

Additionally, there is also the Decision of the Constitutional Court No. 3/PUUVIII/2010 (Indonesian Constitutional Court, 2010), which postulated the private ownership of customary land. It explains that the Constitutional Court recognizes the customary law within the community and considers that Article 33 paragraph 
(3) of the 1945 Constitution claims that all resources within the country controlled by the state and used for the greatest prosperity of the people. The clause of "used for the greatest people's prosperity," is mandating that the state should operate and distribute the resources equitably in a just and sustainable manner. It means that the state has to pay attention to the existing people's rights, both individual rights or collective rights belong to indigenous people (Jayantiari, 2018).

\section{Recognition and Strengthening of Rights to Customary Land in Central Borneo}

Recognition and Strengthening of Rights to Customary Land Formally in Central Borneo

Other than the law mentioned above (UUPA) or Constitutional Court Decision, there is Province Regulation that recognizes customary land. The Central Borneo as a part of Indonesia's province has issued the Provincial Regulation No. 16 of 2008. The regulation states in Article 1 number (19) that customary land and its contents are in the area of Kedamangan (indigenous institution) or the village. The land controlled under customary law, both in the form of the forest nor is it a forest with a broad and clear boundary, both individual and joint property whose existence is recognized by the Damang as a Headchief of an indigenous community (Provincial Regulation on Dayak Customary Institution, 2008). The regulation then implemented a year after, through the implementing regulation which directly related to customary land, that is Governor Regulation (from now on called Pergub) No. 13 of 2009 concerning Customary Land and its Rights in Central Borneo Province (Governor Regulation on Customary Land and its Rights in Central Borneo, 2009).

The right of customary land in Provincial Regulation No. 16 of 2008 and Governor Regulation No. 13 of 2009 divided into two categories, namely communal customary land belongs to the community and individual customary land, which is private property. Customary land owned by the community according to Article 1 number (20) of Local Regulation No. 16 of 2008 is, "inherited ancestral land that is managed and utilized jointly by the heirs as a community, in this case, it can be equally with Customary Rights." While, customary land owned by individuals according to Article 1 number (21) of Provincial Regulation No. 16 of 2008 is "private land which acquired from clearing forests or farming, buying and selling, grants, inheritance, and it can be in the form of gardens or lands (Governor Regulation on Customary Land and its Rights in Central Borneo, 2009; Provincial Regulation on Dayak Customary Institution, 2008)."

In addition to the ownership rights (communal and individual), there is also category named with "customary rights on the land." Further, below are the classifications of customary land owned by communal or individual, and customary rights on land by Governor Regulation No. 4 of 2012 attachment (Central Borneo Governor Regulation on the Amendment of Regulation No. 13 of 2009, 2012): 
Jurnal Hukum

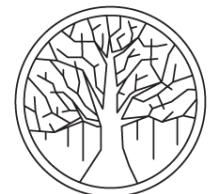

Volume 10, Issue 01, 2019, pp. 11-22

P-ISSN: $1412-6834$

E-ISSN: 2550-0090

Table 1. The Classifications of Customary Land

\begin{tabular}{lll}
\hline $\begin{array}{c}\text { Customary land owned } \\
\text { by Communal }\end{array}$ & $\begin{array}{c}\text { Customary land owned } \\
\text { by individuals }\end{array}$ & \multicolumn{1}{c}{$\begin{array}{c}\text { Customary rights on } \\
\text { land }\end{array}$} \\
\hline $\begin{array}{l}\text { Non-free state domain } \\
\text { (Nonvrij lands domein) }\end{array}$ & $\begin{array}{l}\text { Non-free state domain } \\
\text { (Nonvrij lands domein) }\end{array}$ & $\begin{array}{l}\text { Free state domain (Vrij } \\
\text { lands domein) }\end{array}$ \\
\hline $\begin{array}{l}\text { Unshared } \\
\text { ancestral/parent } \\
\text { inheritance }\end{array}$ & $\begin{array}{l}\text { Self-owned farms, an } \\
\text { ownership exchange by } \\
\text { sale and purchase, or } \\
\text { inheritance grant } \\
\text { exchange }\end{array}$ & $\begin{array}{l}\text { In the form of animals, } \\
\text { fruits, the honey sap, } \\
\text { medicinal ingredients, } \\
\text { religious-magical places } \\
\text { and concocting rights }\end{array}$ \\
\hline The land that can back as & The land that can back as & The land that used not \\
forest or garden & forest or garden & owning it \\
\hline $\begin{array}{l}\text { Can be a place of } \\
\text { residence (in the village), } \\
\text { sacred places, or }\end{array}$ & $\begin{array}{l}\text { Can be a place of } \\
\text { residence (in the village), } \\
\text { religious-magical grave }\end{array}$ & $\begin{array}{l}\text { Hacred places, or } \\
\text { and boundaries }\end{array}$ \\
\hline $\begin{array}{l}\text { The area and boundaries } \\
\text { follow the extent of the } \\
\text { boundary of the formerly } \\
\text { cultivated fields }\end{array}$ & $\begin{array}{l}\text { The area and boundaries } \\
\text { follow the extent of the } \\
\text { boundary of the formerly } \\
\text { cultivated fields }\end{array}$ & $\begin{array}{l}\text { If disturbed, the other } \\
\text { party or owner is having } \\
\text { the right for } \\
\text { compensation }\end{array}$ \\
\hline buying and selling & Transfer of rights through & \\
\hline
\end{tabular}

Recognition and Strengthening of Rights to Customary Land Administratively

Administratively, customary land rights, both the customary rights of communal land and customary land owned by individuals and customary rights on land, are evidenced by customary land ownership certificates (after this called SKT-Adat). SKT-Adat is a letter of recognition proof by the Kedamangan institution on the land of customary rights or customary rights on its land. The certificate of customary land, as it explained in article 10 (1) letter (d) of Central Borneo Provincial Regulation, used as evidence to be registered as land rights following the provisions of the Agrarian Basic Law if the right holder desires to. The authority for making SKT-Adat based on Article 10 (1) letter (b) of Provincial Regulation No. 16 of 2008 is in the Damang as head-chief of indigenous people. In making SKT-Adat, the Damang was assisted by Kerapatan Mantir as Damang's assistant which regulates ownership, management, control, utilization and transfer of customary land ownership and customary rights on the land (Provincial Regulation on Dayak Customary Institution, 2008). Based on Article 8 Paragraph (1) of Governor Regulation No. 13 of 2009, the SKT-Adat and Indigenous Rights on Land that proof the Right of Ownership divides its submission into three categories. Those categories are: 1) the land owned by communal submitted by their heirs; 2 ) the land owned by individual submitted by him/herself; and 3) the land under the indigenous right either submitted by the 
heirs or individual (Governor Regulation on Customary Land and its Rights in Central Borneo, 2009).

\section{Certification Efforts towards SKT-Adat}

Official recognition does not stop at the existence of SKT-Adat. Further effort is the certification of the SKT-Adat, as stated in Article 8 (2) of the Governor Regulation No. $13 / 2009$, and it carried out by the National Land Agency (BPN) (Governor Regulation on Customary Land and its Rights in Central Borneo, 2009). One of the staff of the National Land Agency in Central Borneo stated that the SKT-Adat is the basis for the right to subsequently be made a certificate with the type of ownership certificate by the National Land Agency. So, the position of the SKT-Adat issued by the Damang is equal with the Land Certificate (SKT) issued by the sub-district government.

The author argues that the effort to certify customary land in the form of property rights certificates is the first step in the loss of the element of 'compactness' in the land. When the SKT-Adat is certified to be a certificate of ownership, then the original character on customary land is only known from the fundamental rights for which the land certificate is made. Besides, one thing is sure that shifting the status of SKT-Adat into ownership certificate is raising a higher sale value of the land. Thus, the transfer of ownership because of buying and selling becomes very fast. In that case, it makes the customary nature of the land more forgotten and eventually disappears due to frequent changes in ownership through sale and purchase.

In the end, above chronology obstructs the primary mission of the regional government to strengthen the status of the customary lands of Central Borneo. The author believes that efforts to certify this customary land are like two sides of the coin. On the one hand, a certification effort is a form of local government protection to indigenous peoples towards the certainty of customary land. However, on the other hand, the loss of elements of certified-customary land is real, even though the government intention is protecting the rights of indigenous people.

\section{Efforts to Strengthen Indigenous Land Ownership through Participatory Mapping of Customary Land}

In general, the recognition of individual rights to customary land can be carried out through land registration by Government Regulation Number 24 of 1997 on Land Registration (Government Regulation of the Republic of Indonesia, 1997). Especially for the customary rights of indigenous people, strengthening the existence of these customary lands can be done through two ways, both are: 1) self-initiative land mapping and 2) conducting joint research on the existence of customary rights under Article 5 of Indonesia's Agrarian Ministry No. 5 of 1999 by including customary law experts, indigenous community, non-government organizations, and agencies that manage natural resources (Panggabean, 2011). 
The effort to map customary land is a step that must be taken to avoid conflicts that will occur due to unclear ownership and boundary arrangements. The effort is involving various parties such as the government, National Land Agency, Regional House of Representative, indigenous peoples, and non-government organizations. However, the fact shows other, the role of the Central Borneo Regional Government to map customary lands and incorporate them into the provincial spatial design and the regional draft is minimum.

The Participatory mapping is a mapping that involves community members from planning to forming a map of the region (Kamim, Amal, \& Khandiq, 2018). The mapping process of customary land in Central Borneo have been carried out in a participatory manner by indigenous peoples through the Archipelago Indigenous Peoples Alliance (i.e., Aliansi Masyarakat Adat Nusantara abbreviated as AMAN). For example, the Tumbang Malahoi Indigenous Community in Mas Mountain District, Central Borneo, who asked AMAN for assisting and training them in the making of the Tumbang Malahoi Customary Forest Map (AMAN, 2015).

However, unfortunately, until now, the results of participatory land mapping carried out by indigenous communities have not been mapped in provincial/city spatial design in Central Borneo. Even the results of this participatory mapping of customary lands by indigenous communities throughout Indonesia have also not been registered and registered in the Indigenous Territory Registration Agency (i.e., Badan Registrasi Wilayah Adat abbreviated as BRWA) and the Geospatial Information Agency (i.e., Badan Informasi Geospatial abbreviated as BIG). Thus, coordination between the parties above is needed to immediately carry out participatory mapping of customary lands, not only in Central Borneo but also throughout Indonesia.

\section{Conclusion}

This research concludes that there are serious problems experienced by indigenous people in Central Borneo Province, related to ownership rights to customary land in their territory. One that pays attention is the loss of customary nature of the land belonged to the indigenous community when it legalized administratively as individual ownership.

However, the customary land still recognized by accommodating several ways, which are: 1) Formal recognition; 2) Administrative recognition; 3) Issuance of Customary SKT certificates, and; 4) Mapping customary land in a participatory manner. Those various steps are the way out progress done by the government so far. Thus, it will be possible to minimalize the loss of indigenous characteristic of the land, if all parties jointly agreed to cooperate and consolidate to protect the rights of the indigenous community's land.

The government should seriously deal with and resolve all problems related to the rights of indigenous peoples, not only for indigenous Dayaks in the Province of 
Central Borneo but also for the rights of indigenous peoples throughout Indonesia. For further researchers, it is necessary to develop research locations in the area of other customary law communities in Indonesia, so that the study about land rights of indigenous people holistically covered throughout Indonesia as the entire nation.

\section{References}

Alting, H. (2011). Penguasaan Tanah Masyarakat Hukum Adat (Suatu Kajian Terhadap Masyarakat Hukum Adat Ternate). Jurnal Dinamika Hukum, 11(1). https://doi.org/10.20884/1.jdh.2011.11.1.75

AMAN. (2015). Komunitas Tumbang Malahoi Ikuti PPWA. Retrieved August 5, 2018, from http://aman-kalteng.blogspot.com/2015/10/komunitas-tumbangmalahoi-ikuti-ppwa.html

Cotula, L., \& Mayers, J. (2010). Tenurial dalam Perdebatan REDD: Pokok Persoalan atau Hanya Pelengkap? (1st ed.). Jakarta: HuMa.

Hadikusuma, H. (1999). Hukum Perjanjian Adat. Bandung: Citra Aditya Bhakti.

Hadjon, P. M. (2013). Perlindungan Hukum Bagi Rakyat di Indonesia. Surabaya: Bina Ilmu.

Harsono, B. (2013). Hukum Agraria Sejarah Pembentukan Undang-Undang Pokok Agraris Isi dan Pelaksanaannya. Jakarta: Djambatan.

Hidayat. (2011). Pengelolaan Sumber Daya Alam (Hutan). Jurnal Sejarah Citra Lekha, 15(1), 19-32.

Jayantiari, I. G. A. M. R. (2018). The Harmonization of Law in Regulating the Rights of Customary Community over Natural Resources in Indonesia. Journal of Law, Policy and Globalization, 76, 11-17-17.

Kamim, A. B. M., Amal, I., \& Khandiq, M. R. (2018). Dilema Pemetaan Partisipatif Wilayah Masyarakat Adat di Indonesia: Upaya Resolusi Konflik Agraria dan Kritiknya. Prosiding Senaspolhi, 1(1), 107-120.

Malaka, Z. (2018). Kepemilikan Tanah dalam Konsep Hukum Positif Indonesia, Hukum Adat dan Hukum Islam. Al-Qanun Jurnal Pemikiran Dan Pembaharuan Islam, 21(1).

Marzuki, P. M. (2010). Penelitian Hukum (6th ed.). Jakarta: Kencana.

Panggabean, H. P. (2011). Pemberdayaan Hak Masyarakat Hukum Adat Mendukung Kegiatan Otonomi Daerah. Jakarta: Kerabat.

Pasamai, S., Husen, L. O., Rahman, S., \& Maisa. (2017). Factors Affecting the Protection of Indigenous Peoples' Rights under the National Agrarian Law System (Case Study in Central Sulawesi Province). Imperial Journal of Interdisciplinary Research (IJIR), 3(5), 1958-1970.

Puri, W. H., \& Sulastriyono, S. (2016). Tanah Pekulen dalam Struktur Hukum Agraria di Jawa. Mimbar Hukum, 28(3), 466. https://doi.org/10.22146/jmh.16673

Rosalina. (2010). Eksistensi Hak Ulayat di Indonesia. Jurnal Sasi, 16(3), 44-51.

Salim, M. (2016). Adat Sebagai Budaya Kearifan Lokal Untuk Memperkuat Eksistensi Adat Ke Depan. Al Daulah: Jurnal Hukum Pidana Dan Ketatanegaraan, 5(2), 244-255. https://doi.org/10.24252/ad.v5i2.4845

Soekanto, S. (2006). Pengantar Penelitian Hukum. Jakarta: UII Press.

Soekanto, S. (2011). Hukum Adat di Indonesia. Jakarta: Raja Grafindo Persada.

Sugiswati, B. (2012). Perlindungan Hukum Terhadap Eksistensi Masyarakat Adat Di Indonesia. Perspektif, 17(1), 31-43.

Wardani, W. I. (2018). Kepemilikan Hak Atas Tanah dalam Kerangka Politik Hukum Agraria Nasional. Hukum Dan Dinamika Masyarakat, 15(2), 147-156. 
Jurnal Hukum

Novelty

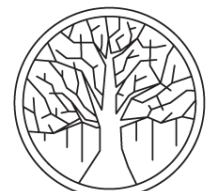

Volume 10, Issue 01, 2019, pp. 11-22

P-ISSN: $1412-6834$

E-ISSN: $2550-0090$

Yono, D., \& Permadi, I. (2016). Keadilan Sosial Masyarakat Adat dalam Pengelolaan Wilayah Pesisir. Seminar Nasional Hukum Universitas Negeri Semarang, 2(01), 299-322. https://doi.org/10.15294/SNH.V2I01.21315

Yusuf, M. A. (2016). Kepastian hukum hak masyarakat hukum adat atas tanah dan sumberdaya alam. Kepastian Hukum Hak Masyarakat Hukum Adat Atas Tanah Dan Sumberdaya Alam, 02(1), 675-685. 